\title{
Malignant Transformation in a Typical Epidermal Cutaneous Cyst
}

\author{
Koutsopoulos V. Anastasios ${ }^{\mathrm{a}, \mathrm{c}}$, Giatromanolaki Alexandra ${ }^{\mathrm{a}}$, \\ Karpouzis Anthony ${ }^{\mathrm{b}}$, Sivridis Efthimios ${ }^{\mathrm{a}}$
}

\begin{abstract}
Although cutaneous epidermal cysts are very common, malignant transformation is a rare event. Even more rare is a change into squamous cell carcinoma. Such a case is presented in this report. The clinical and histological characteristics together with the differential diagnosis and the pathogenesis of this unexpected development are discussed. We recommend that all lesions presumed to be epidermal cysts should be completely excised and submitted for histological examination.
\end{abstract}

Keywords: Cutaneous epidermal cyst; Malignant transformation; Squamous cell carcinoma; Acantholytic

\section{Introduction}

Epidermal cysts are extremely common lesions of the skin. They are solitary, slowly growing, with a predilection for the trunk, neck and face. They measure $1-4 \mathrm{~cm}$ in diameter, although larger variants have also been reported. Epidermal cysts are usually located in the mid and lower dermis. They are lined by stratified squamous epithelium showing epidermal keratinisation in a flattened surface epithelium. As such, they are thought to be derived from, or mimic to, the infundibular portion of the hair follicle [1]. Malignant trans-

Manuscript accepted for publication March 23, 2012

a Departments of Pathology, Faculty of Medicine, Democritus University of Thrace, Alexandroupolis, Greece

${ }^{b}$ Departments of Dermatology, Faculty of Medicine, Democritus University of Thrace, Alexandroupolis, Greece

${ }^{c}$ Corresponding author: Koutsopoulos V. Anastasios, Department of pathology, University General Hospital of Alexandroupolis, 68100,

Thrace, Greec. Email: akoutsop@med.duth.gr

doi:10.4021/jmc626w formation of these cysts are known to occur, although only rarely and includes basal and squamous cell carcinoma [2-4], Paget's disease [2], Bowen's disease [5], mycosis fungoides $[6,7]$, Merkel cell carcinoma [8] and malignant melanoma [9]. It is worth mentioning, however, that among the several publications reporting on malignant transformation of an epidermal cyst, those that are relating to squamous cell carcinoma and are well documented, have an incidence between $0.011-0.045 \%[4,10-14]$.

We present here a case of squamous cell carcinoma because of its rarity that, to the best of our knowledge, is the twentieth arising in a typical epidermal cyst of the skin.

\section{Case Report}

A 69 years old female was referred to the Department of Surgery, University General Hospital of Alexandroupolis, complaining of a slowly growing mass on her cheek of 1.5-years duration. The mass was painless, mobile and cystic. The overlying epidermis appears normal. Otherwise, the clinical history of the patient was unremarkable. The cyst was completely excised with a 4-mm margin of normal tissue. Macroscopic examination of the specimen revealed a unilocular cyst of maximum diameter $0.9 \mathrm{~cm}$, confined in the reticular dermis and filled with amorphous whitish material. There was a discrete thickening in a focal area of the wall. Microscopic examination showed a moderately differentiated squamous cell carcinoma, acantholytic in type, developing from the wall of an otherwise typical cutaneous epidermal cyst (Fig. 1a, b). The cyst was lined by stratified squamous epithelium with a well-defined granular layer, exhibiting keratinization (Fig. 1a, b). There was disruption of the cystic wall, accompanied by a mixed inflammatory cell infiltrate of the adjacent stroma. Multiple sections failed to show a connection of the cyst with the overlying epidermis. The thickened area of the cyst was corresponded to a moderately differentiated invasive squamous cell carcinoma of acantholytic cell type (Fig. 1a, b, c). The tumour was arising from the basal layer of the epithelium of the cyst, sharply, without the presence of any dysplastic changes (Fig.1a, b). The tumour cells showed nuclear polymorphism and hyperchromatism 


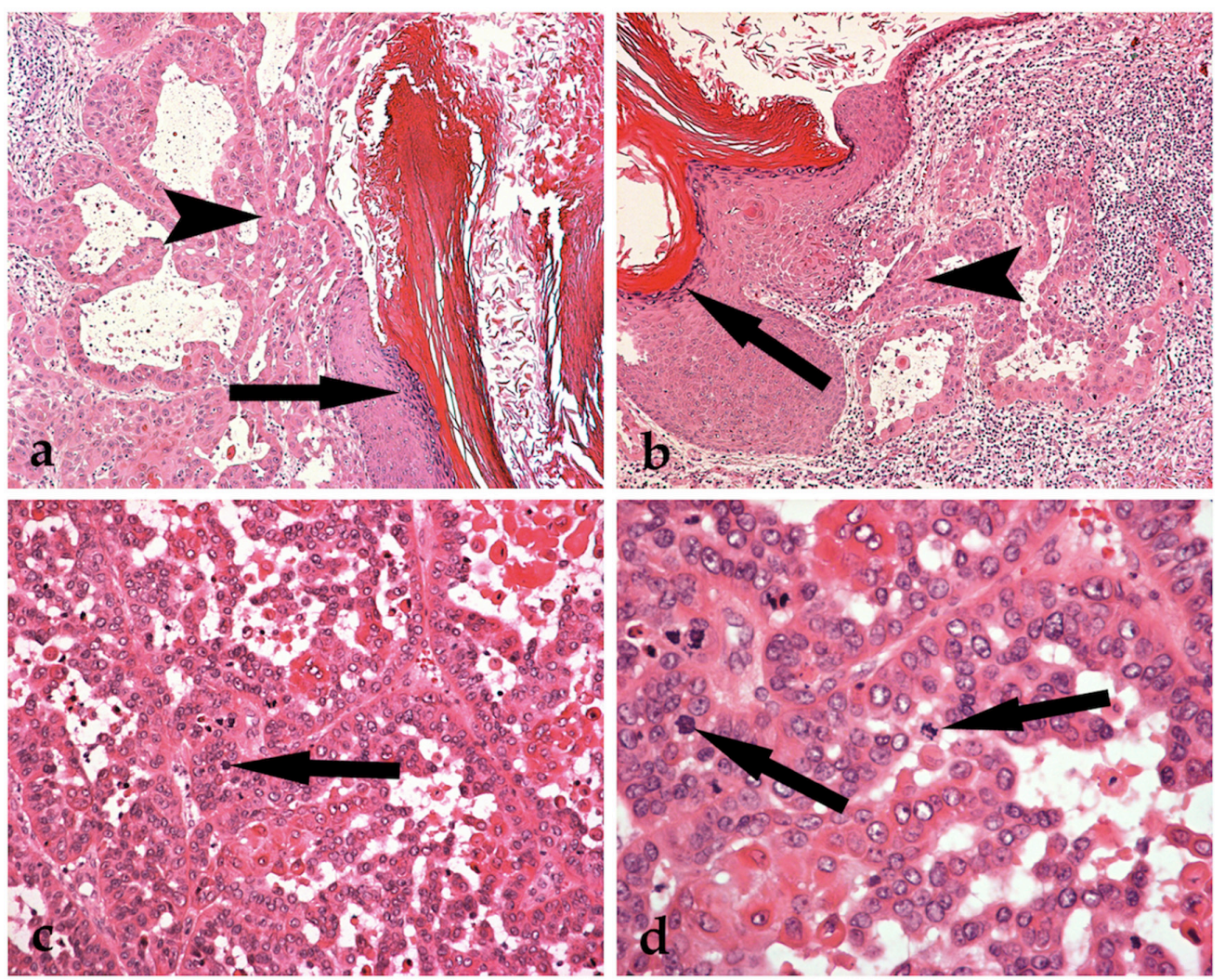

Figure 1. A typical epidermal cyst exhibiting granular cell layer and keratinisation ( $a$ and b: arrows). Malignant transformation into an acantholytic squamous cell carcinoma, without any dysplastic changes of the epithelium of the epidermal cyst ( $a$ and b: arrowheads) (Haematoxylin and eosin stained sections, x 100). Tumour cells showing nuclear polymorphism with hyperchromatism and keratinisation, loss of cellular cohesion and frequent mitoses (c and d: arrows) (Haematoxylin and eosin stained sections, c: $x 200$ and d: x 400).

with keratinization and loss of cellular cohesion, resulting in detached neoplastic cells (Fig. 1c, d). Mitoses were frequent (Fig. 1d). The uppermost dermis showed signs of sun damage in the form of solar elastosis. The surgical margins were free of tumour. Clinical investigation for occult malignancy elsewhere in the body revealed no secondary sites. The patient is free of disease four months postoperatively.

\section{Discussion}

Although epidermal cysts of the skin are excessively frequent, malignant transformation is a rare event. It has however been described on several occasions, in the form of Bowen's disease, Paget's disease, Bowenoid papulosis, mycosis fungoides, Merkel cell carcinoma, basal and squamous cell carcinoma [2-9]. To date, nineteen well-documented cases of malignant transformation into squamous cell carcinoma have been reported in the walls of epidermal cysts, with an incidence ranging between 0.011 and $0.045 \%$ [4, 13, 14]. Our case is, in fact, the twentieth [13]. Most cases occur in adulthood, with a mean of 56.1 years (range 21 - 80 years) and a male predominance $(70 \%)$, although our patient was a female aged 69 years. The most common site of involvement is the head and neck (as in our case), while other, less usual, sites include the trunk and limb. The lesions display a mean diameter of $5 \mathrm{~cm}$ (range from 1.5 to $13 \mathrm{~cm}$ ) and a mean duration of 104 months (range from 2 to 480 months). Three cases of metastatic disease have been described [15-17]. Our case is a squamous cell carcinoma, acantholytic in cell type [18], the second in the medical literature, having a moderate differentiation.

The differential diagnosis should always include malignant transformation in an epidermal or a trichilemmal proliferating cyst and pseudo-carcinomatous hyperplasia in a ruptured cyst. With regard to the pathogenesis, exposure of the skin to ultra-violet radiation is the most common cause for the development of squamous cell carcinoma [19]. Human papillomavirus (HPV) infection has also been implicated, although Morgan et al [10] failed to show an etiological correlation between HPV and the development of squamous carcinoma in the limited number of cases studied. Squa- 
mous-cell carcinoma is more likely to develop in an injured or chronically diseased skin [20].

Although it has been advocated that malignant transformation should be suspected in large epidermal cysts with rapid growth, ulceration or fistulas and lack of response to medical treatment or local recurrence [13], none of the above characteristics were observed in our case. In fact, we may comment that squamous cell carcinoma may arise in a clinically benign cyst and have a normal gross appearance [4]. It is, therefore, recommended that all lesions presumed to be epidermal cysts should be completely excised and submitted intact for a detailed histological examination.

\section{Conflict of Interests}

The authors declare no conflict of interests.

\section{References}

1. Weedon D. Cysts, sinuses and pits. Skin Pathology. Second ed: Churchill Livingstone; 2002. p. 504-5.

2. Vicente J, Vazquez-Doval FJ. Proliferations of the epidermoid cyst wall. Int J Dermatol. 1998;37(3):181-185.

3. Tsujita-Kyutoku M, Danbara N, Yuri T, Nikaido Y, Hatano T, Tsubura A. Basal cell carcinoma arising from a keratinous cyst of the skin: a case report and review of the literature. Med Mol Morphol. 2005;38(2):130-133.

4. Cameron DS, Hilsinger RL, Jr. Squamous cell carcinoma in an epidermal inclusion cyst: case report. Otolaryngol Head Neck Surg. 2003;129(1):141-143.

5. Shelley WB, Wood MG. Occult Bowen's disease in keratinous cysts. Br J Dermatol. 1981;105(1):105-108.

6. Aloi F, Tomasini C, Pippione M. Mycosis fungoides and eruptive epidermoid cysts: a unique response of follicular and eccrine structures. Dermatology. 1993;187(4):273277.

7. Slater DN, Messenger AG, Rooney N. Mycosis fungoides in an epidermoid cyst. Histopathology. 1985;9(6):659662.
8. Perse RM, Klappenbach RS, Ragsdale BD. Trabecular (Merkel cell) carcinoma arising in the wall of an epidermal cyst. Am J Dermatopathol. 1987;9(5):423-427.

9. Swygert KE, Parrish CA, Cashman RE, Lin R, Cockerell CJ. Melanoma in situ involving an epidermal inclusion (infundibular) cyst. Am J Dermatopathol. 2007;29(6):564-565.

10. Morgan MB, Stevens GL, Somach S, Tannenbaum M. Carcinoma arising in epidermoid cyst: a case series and aetiological investigation of human papillomavirus. $\mathrm{Br} \mathrm{J}$ Dermatol. 2001;145(3):505-506.

11. Lopez-Rios F, Rodriguez-Peralto JL, Castano E, Benito A. Squamous cell carcinoma arising in a cutaneous epidermal cyst: case report and literature review. Am J Dermatopathol. 1999;21(2):174-177.

12. Yaffe HS. Squamous cell carcinoma arising in an epidermal cyst. Arch Dermatol. 1982;118(12):961.

13. Anton-Badiola I, San Miguel-Fraile P, Peteiro-Cancelo A, Ortiz-Rey JA. [Squamous cell carcinoma arising on an epidermal inclusion cyst: a case presentation and review of the literature]. Actas Dermosifiliogr. 2010;101(4):349-353.

14. Chiu MY, Ho ST. Squamous cell carcinoma arising from an epidermal cyst. Hong Kong Med J. 2007;13(6):482-484.

15. Arianayagam S, Jayalakshmi P. Malignant epidermal cyst: a case report. Malays J Pathol. 1987;9:89-91.

16. Nemoto I, Shibaki A, Aoyagi S, Tsuji-Abe Y, Shimizu $\mathrm{H}$. Aggressive squamous cell carcinoma developing in a giant epidermal cyst of the abdomen. Int J Dermatol. 2006;45(12):1444-1446.

17. Jehle KS, Shakir AJ, Sayegh ME. Squamous cell carcinoma arising in an epidermoid cyst. Br J Hosp Med (Lond). 2007;68(8):446.

18. Malone JC, Sonnier GB, Hughes AP, Hood AF. Poorly differentiated squamous cell carcinoma arising within an epidermoid cyst. Int J Dermatol. 1999;38(7):556-558.

19. Alam M, Ratner D. Cutaneous squamous-cell carcinoma. N Engl J Med. 2001;344(13):975-983.

20. Davies MS, Nicholson AG, Southern S, Moss AH. Squamous cell carcinoma arising in a traumatically induced epidermal cyst. Injury. 1994;25(2):116-117. 